\title{
The Development of Academic Vocabulary among Arabic Native Speaking Middle School Pupils: How Much Do They Really Know?
}

\author{
Bahaa Makhoul1,2,3*, Elite Olshtain ${ }^{2}$, Katrina Sabah ${ }^{3}$, Thuraia Copti-Mshael ${ }^{3}$ \\ ${ }^{1}$ Oranim Academic College of Education, Kiryat Tevo'n, Israel \\ ${ }^{2}$ The Hebrew University Jerusalem, Jerusalem, Israel \\ ${ }^{3}$ Center for Educational Technology, Tel-Aviv, Israel \\ Email: ${ }^{\star B}$ aham@cet.ac.il
}

How to cite this paper: Makhoul, B., Olshtain, E., Sabah, K., \& Copti-Mshael, T. (2018). The Development of Academic Vocabulary among Arabic Native Speaking Middle School Pupils: How Much Do They Really Know? Psychology, 9, 323-339. https://doi.org/10.4236/psych.2018.93020

Received: November 17, 2017

Accepted: March 13, 2018

Published: March 16, 2018

Copyright (c) 2018 by authors and Scientific Research Publishing Inc. This work is licensed under the Creative Commons Attribution International License (CC BY 4.0).

http://creativecommons.org/licenses/by/4.0/ (c) () Open Access

\begin{abstract}
The purpose of this study is to obtain a more fine-grained understanding of academic vocabulary knowledge in Arabic as L1 among middle school pupils. Accordingly, 1197 middle school Arabic native speaking pupils, representing the different Arab subgroups in Israel, have participated in this study. In the first phase of the study, a corpus based Arabic academic vocabulary list (AAVL) was developed, setting ground for developing three assessment tests that measured receptive vocabulary knowledge on different levels, commencing from mere recognition to application and production of academic vocabulary in context. In the second phase, differences in academic vocabulary knowledge were assessed in relation to age ( $7^{\text {th }}$ and $9^{\text {th }}$ grades) and Arab sub-group (General Arab, Druze and Bedouin). Significant main effects were found for age and Arab subgroup. Significantly higher performance was noted among $9^{\text {th }}$ graders when compared to $7^{\text {th }}$ graders with the Druze sub group outperforming the general Arab and the Bedouin subgroup. The latter sub-group, characterized by the lowest socio-economic background showed the poorest performance. Additionally, three-way interaction was found between academic vocabulary knowledge level, age and Arab subgroup. In both $7^{\text {th }}$ and $9^{\text {th }}$ grade, significant differences were found between the Arab subgroups on the academic cloze test and production of academic vocabulary only. Post-hoc comparisons showed that in both age groups, the Druze subgroup achieved the highest performance in both tests. Significant differences between the general Arab and Bedouin subgroups were noted on the academic cloze test but not on the production of academic vocabulary test. The results of the study and its implications are discussed.
\end{abstract}




\section{Keywords}

Academic Vocabulary, Academic Literacy, Arabic, Diglossia, Socio Economic Status (SES)

\section{Introduction}

Middle school marks a transitional stage for pupils, setting new academic demands (Augustine, Juvonen, Le, Kaganoff, \& Constant, 2004). Middle school pupils are exposed to more intricate, linguistically richer and more diverse texts, escalating in their complexity through the grades (Fang, Schleppegrell, \& Cox, 2006). As such, arrival at proficiency of academic language is crucial for academic success, enabling adequate coping with the different encountered scholastic material and assignments (Hakuta, Butler, \& Witt, 2000; Short \& Fitzsimmons, 2007; Townsend, Filippini, Collins, \& Biancarosa, 2012). Academic language is a broad construct that falls along a continuum, being one alternative of several other terms such as language of education, language of schooling and scientific language (Halliday, 1993; Schleppegrell, 2001). Here, we refer to academic language as the language of school, where its mastery entails knowledge and applicability of "general and content-specific vocabulary, specialized or complex grammatical structure and multifarious language functions and discourse structures" (Bailey, 2007: p. 10).

Academic vocabulary, characterizing academic writing, is one of the prominent contributors to academic texts abstraction and density (Townsend, Filippini, Collins, \& Biancarosa, 2012). As texts become more complex, reading comprehension and learning process rely greatly on academic word knowledge. Indeed, poor academic vocabulary knowledge is thought to be one of the main challenges for meaning construction (Stahl \& Shiel, 1992; Cummins, 2003) where depicting appropriate academic vocabulary within a specific discipline is associated with success in that subject (National Institute for Literacy, 2007). However, it seems that acquiring academic vocabulary is extremely demanding task for pupils, among others, due to its complexity and low frequency in daily language.

\subsection{Academic Vocabulary and Its Development: On the Case of Diglossic Arabic}

Academic words constitute $8 \%-10 \%$ of academic text vocabulary and thus are crucial for comprehending expository texts (Nation, 2001; Hyland \& Tse, 2007). The concept of academic vocabulary remains controversial, where multiple and inconsistent definitions have been proposed. Here, academic vocabulary refers to a general cluster of words that are used across different content areas (e.g. History, science, technology), are necessary for learning and are difficult to acquire (Townsend, 2009). 
Previous work indicates that students' poor academic vocabulary knowledge affects their academic gains (Cohen, Glasman, Rosenbaum-Cohen, Ferrara, \& Fine, 1988; Coxhead, 2000; Nation, 2001). Consequently, several attempts have been made to establish academic word lists that serve to develop appropriate intervention programs for fostering academic vocabulary, mostly among English learners (e.g. Campion \& Elley, 1971; Coxhead \& Nation, 2001; Gardner \& Davies, 2014; Ghadessy, 1979; Lynn, 1973; Praninskas, 1972; Xue \& Nation, 1984). However, the examination of academic language development among Arabic native speakers remains scarce and unestablished. Additionally, taking into account the specific linguistic features of the Arabic language and its impact on literacy development, a finer toned examination is advisory.

Several properties of the Arabic language seem to obstruct Arabic academic vocabulary acquisition, especially its diglossic nature (i.e. the linguistic gap between its spoken and written form; Ferguson (1959)). There is a large body of evidence that points to the great impact of Arabic diglossic nature on language development, including oral language and later reading skills (e.g., Abu-Rabia, 2000; Saiegh-Haddad, 2017), accounting in part to the low attainments in reading literacy tests of Arabic native speaking pupils both on national and international scales (Zuzovsky, 2005, 2010; Abu-Asba, 2005; Karmarski \& Mevarech, 2004; Mevarech \& Karmarsky, 2007). Moreover, the complex linguistic characteristics of Arabic morphological, semantic, syntactic and phonological structures may constitute yet another challenge for literacy acquisition in general and academic vocabulary development in specific (for a full review about Arabic linguistic properties see Saiegh-Haddad \& Henkin-Roitfarb, 2014).

\subsection{The Arab Population in Israel and Literacy}

The Arab population in Israel consists $25 \%$ of the Israeli population, with $92 \%$ of the former living in an exclusively Arab inhibited towns and villages whereas the others live in an intermixed Jewish-Arab cities (Yonay, Yaish, \& Kraus, 2015). The Muslim community, including the Bedouins, constitutes about $83 \%$ of the Arab population in Israel, the Christians 9\% and the Druze 8\% (Central Bureau of Statics, 2016). The Christian population is characterized by higher academic achievements, higher marriage mean age, lower birth rate and larger income (Khattab, 2002; Kraus \& Yonay, 2000). The Druze and the Muslim community, excluding the Bedouin population, are found to share equivalent socio-economic conditions (Yonay, Yaish, \& Kraus, 2015). In contrast, the Bedouin population is nomadic agrarian that live in recognized and unrecognized villages. Among the latter, poverty rate was nearly $80 \%$ in 2004 . In general, when comparing the Socio-economic status (SES) of the Arab to the Jewish population in Israel, immense gaps are encountered, favouring the latter. In comparison to $14 \%$ of Jewish families, $47 \%$ of the Arab population in Israel live in poverty (National Insurance Institute of Israel, 2016) with the Bedouin population ranking on the bottom of the Israeli's SES scale (Abu-Bader \& Gottlieb, 2009; Rudnitzky, 2012). 
The socio-cultural heterogeneity of the Israeli population echoes also in the structure of the education system. Along the years, separate Arab and Jewish educational systems have been operated. The former is further divided into three sub-systems: general Arab (Muslims and Christians), Druze and Bedouin. To meet the language and cultural differences both between the Arab and Jewish population as well as those between the three Arab subgroups, different curriculums are applied. This separation in turn makes education in Israel highly susceptible to political agendas, ethno-religious Hierarchy and discrimination (Adalah, 2011; Friedlander, Okun, \& Goldscheider, 2016).

Socio-culture factors are found to impact academic achievements in general and literacy status in specific among the Israeli population, as seen on both national and international tests. For example, as indicated by PISA results (OECD, 2014), 50\% of Arabic speaking pupils are below the expected literacy proficiency level, where poorer performance has been encountered among the Arab sector in Israel when compared to the Jewish sector (Israeli Ministry of Education, 2015). Within the Arab sector, higher literacy achievements are encountered among the Druze pupils when compared to the general Arab subgroup, across all disciplines, whereas the poorest performance was noted among the Bedouin subgroup (Knesset Research and Information Center, 2013; MJB, 2015; Edi-Rokah et al., 2011). These observed literacy gaps seem to widen in middle school (Edi-Rokah et al., 2011). Furthermore, according to the Israeli Ministry of Education 2013-2015 reports (MJB, 2015), only 33\% of Arab high school pupils were eligible for a matriculation certificate in comparison to $50 \%$ in the Jewish sector. Moreover, higher dropout and violence rates are observed in Bedouin junior highs, having only $20 \%$ matriculation eligibility rate.

\subsection{Challenges in Vocabulary Assessment}

Devising a valid measure for vocabulary assessment can be challenging as the construct of word knowledge remains controversy (Pearson, Hiebert, \& Kamil, 2007). One of the earliest comprehensive definitions of word knowledge can be traced to Richards (1976), who proposed that knowing a word involves broad knowledge of the word semantics, manner of utilization, its morphological properties, the syntactical forms associated with it and knowledge of its semantic association with other words, as well as the limitation of its usage in different contexts. However, such definition remains descriptive and incomplete, as it fails neither to account for the developmental aspects of the different word knowledge levels nor for its underlying shared mechanisms (Schmitt \& Meara, 1997). In an attempt to shift away from descriptive frameworks, Meara (1996) suggested that word knowledge encompasses three main distinctive competencies, learners' vocabulary knowledge: the size of the lexicon, the automaticity by which lexical items are accessed and the richness of the learners' semantic network. Alternatively, Cockrum \& Shanker (2012) suggested that the purpose of assessing pupils' vocabulary is to assess the adequacy of their vocabulary know- 
ledge to their grade level and knowledge of words that are required for immediate instruction. They proposed a five word knowledge levels: 1) Absolute lack of familiarity with a word (no recognition of a word); 2) Recognizing the word but not knowing its meaning; 3 ) Inferring the word meaning from context while having only limited understanding of its meaning; 4) Adequate understanding of the word that appears in context; 5) Familiarity with the multiple meanings of the word (if it exists) and ability to utilize it for communication purposes (speaking and writing) and in thinking.

Other distinction of vocabulary knowledge relates to the breadth and depth of vocabulary. The former refers to number of words that one has some familiarity with (Nation, 2001) and the latter refers to the level of one's understanding to the different aspects of the word. Breadth of vocabulary knowledge is by itself a multi-componential construct that encompasses pronunciation, spelling, morphological and syntactic properties, registers, meaning and semantic associations and collocational properties (Richards, 1976; Qian, 1999).

\subsection{The Current Study}

For the first time, the current study attempted to investigate academic vocabulary knowledge among middle school Arab native speakers, shedding light on yet another possible underlying factor in the experienced literacy challenges. To this end, we compared academic vocabulary knowledge of $7^{\text {th }}$ and $9^{\text {th }}$ grade (the start and end of middle school). In addition, due to the gaps in literacy achievements between the Arab subgroups, we also endeavored on examining differences in academic vocabulary knowledge between the three Arab subgroups. Accordingly, three academic vocabulary measures were developed, utilizing a variation of test formats such as self-check tests, requiring the test taker to indicate whether he is familiar with a presented words or not, cloze task and sentence production task. For building the assessment tests, a corpus-based Arabic academic list for middle school was developed. The list contains the 55 most frequent word-roots appearing in middle school textbooks across four subject areas: history, civics, technology, science, and geography. It is worthy to note that the rationale for clustering the words based on their roots is due to Arabic morphological structure. As other Semitic languages, Arabic words are derived from "roots" (\ذزjaðer), mostly trilateral consonant roots that are inserted within a word pattern, either derivational or inflectional. As it conveys the core meaning of the word, Arabic dictionaries are typically organized alphabetically according to word roots (Saiegh-Haddad \& Henkin-Roitfarb, 2014).

The aims of the study are as follows:

1) Examining varied levels of academic vocabulary knowledge among Arabic native speaking pupils in $7^{\text {th }}$ and $9^{\text {th }}$ grades.

2) Investigating the differences in academic vocabulary knowledge between the Arab subgroups in Israel: General Arab, Druze and Bedouin subgroup. 


\section{Method}

\subsection{Participants}

The current study included 1197 middle school Arabic native speakers $\left(7^{\text {th }}\right.$ and $9^{\text {th }}$ graders) from ten different schools in Israel, representing the different Arab subgroups in Israel (i.e., General Arab subgroup, Druze subgroup and Bedouin subgroup, see Table 1 below). In $7^{\text {th }}$ grade, age mean score is $12.98(S D=.36)$ and in $9^{\text {th }}$ grade $14.96(S D=.35)$.

In addition, four Arabic junior-high teachers assisted in mapping the academic vocabulary that is necessary to cope with the materials in the various disciplines (history, geography, civics, science and technology). All the participating teachers had obtained their M.A. degree in Arabic language and had more than 10 years of teaching experience. Another 46 teachers, who teach various disciplines, participated in rating the necessity of the mapped words for successful academic performance in middle school (see Section 2.3.1 developing corpus-based academic vocabulary list procedure). The teachers who participated in the mapping processes were selected from schools that were not among those selected for the test administration.

\subsection{Tools}

To investigate academic vocabulary knowledge, three tests were devised, each addressing different knowledge level. The target words were selected from the Arab Academic Word List (AAWL) that was developed for the purposes of the current study (see Section 2.3.1 for the developing process):

Table 1. The pupils' distribution in the study as a function of group affiliation, age group and gender.

\begin{tabular}{|c|c|c|c|c|}
\hline \multirow{2}{*}{$\begin{array}{l}\text { Group } \\
\text { affiliation }\end{array}$} & \multirow{2}{*}{ Age group } & \multicolumn{2}{|c|}{ Gender } & \multirow{2}{*}{ Tota } \\
\hline & & Boys & Girls & \\
\hline \multirow{3}{*}{ General Arab } & $7^{\text {th }}$ grade & 272 & 299 & $571^{1}$ \\
\hline & $9^{\text {th }}$ grade & 132 & 155 & $287^{2}$ \\
\hline & Total & 404 & 454 & 858 \\
\hline \multirow{3}{*}{ Bedouin } & $7^{\text {th }}$ grade & 42 & 48 & 90 \\
\hline & $9^{\text {th }}$ grade & 48 & 42 & 90 \\
\hline & Total & 90 & 90 & 180 \\
\hline \multirow{3}{*}{ Druze } & $7^{\text {th }}$ grade & 64 & 39 & 103 \\
\hline & $9^{\text {th }}$ grade & 27 & 29 & 56 \\
\hline & Total & 91 & 68 & 159 \\
\hline \multirow{3}{*}{ Total } & $7^{\text {th }}$ grade & 378 & 386 & 764 \\
\hline & $9^{\text {th }}$ grade & 207 & 226 & 433 \\
\hline & Total & 635 & 674 & 1197 \\
\hline
\end{tabular}

${ }^{1}$ Eight $7^{\text {th }}$ graders within the General Arab subgroup didn't report their gender; ${ }^{2}$ Three $9^{\text {th }}$ graders within the General Arab subgroup didn't report their gender. 
1) Yes-No Academic vocabulary Test the test included 93 words presented inself-check list, containing the 35 most frequent word-roots list (out of 55 roots), each accompanied by either two or three derived academic words as following: the most frequent word and additional one or two words that denote distinct meaning (see procedure section for the academic vocabulary list developing). In total, the students were asked to check-mark whether they know the meaning of each presented word. The total score was calculated as the total number of checked words. Aftermath, percentage scores (\%) were calculated for each pupil. Alpha Cronbach value is 95 .

Table 2 presents an example of the test. For the sake of convenience, the phonetic transcriptions as well as the word meaning in English were added after each word (third column from left). The students were asked to determine whether they are familiar with the meaning of each word or not by drawing a check-mark in the suitable column (fourth or fifth column).

The usage of the described test is due to the communality of using yes-no tests for assessing vocabulary knowledge in both L1 and L2, where it was found as a reliable predictor of reading ability (Anderson \& Freebody, 1983). For the purpose of the current study, an adaption of Meara (2010) yes-no vocabulary test was used. Unlike the original test that included several levels of testing and non-words to penalize over estimation, in the current test only academic words were included thus dispensing of non-words inclusion. In addition, the words are organized in relation to their roots due to the morphological structure of

Table 2. Example of the questionnaire structure and items.

\begin{tabular}{|c|c|c|c|c|}
\hline Column 1 & Column 2 & Column 3 & Column 4 & Column 5 \\
\hline Serial number & Word root & Words & $\begin{array}{l}\text { Word meaning } \\
\text { is familiar }\end{array}$ & $\begin{array}{c}\text { Word meaning is } \\
\text { unfamiliar }\end{array}$ \\
\hline \multirow{3}{*}{1} & & $\begin{array}{c}\text { مادّةٌ } \\
\text { |madatun } \backslash \\
\text { (i.e. Material) }\end{array}$ & & \\
\hline & $\begin{array}{l}\text { د.d.p } \\
\mid \text { m.d.d }\end{array}$ & $\begin{array}{c}\text { تَستِدُِ } \\
\text { |tastamidul } \\
\text { (i.e. Derives) }\end{array}$ & & \\
\hline & & 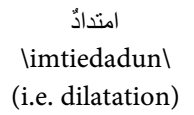 & & \\
\hline \multirow{3}{*}{2} & & 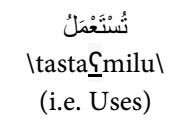 & & \\
\hline & $\begin{array}{l}\text { J.P.ع } \\
\mid \underline{\text { s.m.l| }}\end{array}$ & $\begin{array}{c}\text { عملية } \\
\text { |Samaliyatu } \backslash \\
\text { (i.e. Operation) }\end{array}$ & & \\
\hline & & 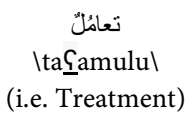 & & \\
\hline
\end{tabular}


Arabic (see Table 2).

2) Academic clozetest. The test included two sections. In the first section, twenty academic words were omitted from a 358 words informational text. The pupils were required to fill the blanks with the suitable target word, selecting it from a wordbank that appeared under the text. In addition to the target words, five distractors were included (overall 25 words: 5 distractors and 20 target words). One point was granted for each correct answer with a total of 20 points for this section. Alpha-Cronbach is 96 .

In the second section, two comprehension questions were included, assessing the deeper understanding of the texts' main ideas. First, the pupils were asked to identify the main idea of the text by selecting the adequate title for the completed cloze (multiple-choice question). One point was given for a correct answer. Moreover, the pupils were asked to justify their answer (an open-end question). A correct answer was given one point.

An overall percentage score was calculated for each pupil as follow: the cloze task constituted $50 \%$ of the overall score and the multiple-choice question as well as the open-end question constituted $25 \%$ each.

3) Academic Vocabulary Production in Context. the pupils were required to select seven different academic words, appearing in the first evaluation test (yes-no academic vocabulary test), and to compose a sentence for each selected word. Score range was 0 - 14. Each inappropriate response (i.e. either a missing response or incorrect utilization of the word in context) received: a) points; a partly correct response (i.e. correct allocation of the word in context but incorrect syntactical and \or morphological structures received); b) point and fully appropriate response; c) points (semantically and morpho-syntactically correct). Ultimately, a percentage score was calculated for each pupil. Alpha-Cronbach is .89 .

\subsection{Procedure}

Developing a corpus-based academic vocabulary list. Accredited Arabic middle-school teachers that underwent professional training by the head of research team conducted the mapping process. First, 8118 academic words were mapped from seven middle-school textbooks from different knowledge domains (history, civics, geography and science and technology). Excluding repetitions, 2532 academic words were identified, derived from 684 word-roots. Words and word-root frequencies were calculated across the different disciplines, leaving only words with frequency value above seven. We crossed-checked the high frequency words between the different knowledge disciplines, creating a unified lexicon that included 184 joint word-roots. From the remained 184 word-roots, the teachers rated the 40 necessary word-roots for adequate coping with the appearing expository texts in junior high schools. The selected most frequent words were cross-checked with the 50 most frequent words out of the 184 word-roots, yielding 45 word-roots. To complete a 50 word-root list, five novel high fre- 
quency word-roots (with accordance to the teachers' rating) were added. Additional five non-crossed checked words were added as their frequency rates were very similar to the last five ranked word-roots in the 45 identified high frequency word-roots list. The fifty-five word-root list was then utilized for developing the evaluation tests.

Test administration. At the end of scholastic year, a 90-minuteacademic vocabulary battery was administrated by middle-school Arabic language teachers in the different selected schools during Arabic language lesson. Each pupil received a test booklet containing the three evaluation tasks with the relevant instructions.

\subsection{Data Analysis}

All test scores were converted to percentage scores and Statistical Package for the Social Sciences (SPSS) was used for data analysis. To examine differences in pupils' knowledge, application and production of academic vocabulary, $3 \times 2 \times 2$ mixed factors analysis of variance (MANOVA) was performed. Additionally, multivariate analysis of variance was conducted with Bonefroni's as a post hoc test.

\section{Results}

Participants that deviated more than $3 S D$ from their group's mean were excluded from analysis (6 participants). To examine differences in academic vocabulary knowledge between the age groups and to check for possible modulating effect for socio-cultural differences between the Arab subgroups, three-way analysis of variance was conducted. Test knowledge level (yes-no academic vocabulary test, academic cloze test and academic vocabulary production in Context test) were inserted as within subject variable and age ( $7^{\text {th }}$ and $9^{\text {th }}$ grade) and Arab subgroup (General Arab, Druze and Bedouin) as a between subject factors. The results of analysis are presented in Table 3.

The results pointed to a significant main effect for academic vocabulary knowledge, pointing to higher attainments on the yes-no academic vocabulary

Table 3. Differences in academic vocabulary declarative knowledge, application and production between age groups.

\begin{tabular}{cccccc}
\hline & $\mathbf{7}^{\text {th }}$ grade & $\mathbf{9}^{\text {th }}$ grade & F & $\boldsymbol{\eta}^{2}$ \\
\cline { 2 - 3 } & $\mathbf{M}(\mathrm{SD})$ & $\mathbf{M}(\mathrm{SD})$ & & \\
\hline Academic Vocabulary & 92.87 & 94.91 & & $11.59^{* * *}$ & .01 \\
Declarative Knowledge & $(11.02)$ & $(9.23)$ & & & \\
Academic Vocabulary & 44.16 & 67.89 & & $52.30^{* * *}$ & .04 \\
Application in Context & $(29.52)$ & $(27.66)$ & & \\
Academic Vocabulary & 18.34 & 23.61 & & $7.57^{* * *}$ & .01 \\
Production in Context & $(16.52)$ & $(16.42)$ & & \\
\hline
\end{tabular}

${ }^{* * *} p<.001$. 
test $(M=94.03, S D=9.1)$ when compared to attainments on the academic cloze test $(M=49.74, S D=30.87)$ with the lowest attainments noted on the academic vocabulary Production in context test $(M=20.11, S D=16.63)$. In addition, significant main effect was found for age group. Higher attainments were observed among $9^{\text {th }}$ grades $(M=61.04, S D=0.82)$ when compared to $7^{\text {th }}$ graders $(M=$ $61.62, S D=.67)$. Significant main effect was also found for Arab subgroup. The Druze subgroup $(M=61.62, S D=10.59)$ showed the highest performance, followed by the General Arab subgroup $(M=54.02, S D=14.71)$ whereas the Bedouin subgroup showed the poorest performance $(M=51.46, S D=12.58)$.

No significant interaction was found between Age group and Arab subgroup. In contrast, significant two-way interaction was found between academic vocabulary knowledge and age group as well as between academic vocabulary knowledge and Arab age group. These two-way interactions were further qualified by a higher order interaction between academic vocabulary knowledge, age group and Arab subgroup. To unravel the source of this interaction a multivariate test of analysis was performed separately for each age group, employing Benforoni post-hoc test. In both $7^{\text {th }}$ and $9^{\text {th }}$ grade, differences between the Arab subgroups were found on the academic cloze test and application of academic vocabulary test but not on the yes-no academic vocabulary test (see Table 4 for statistics). Bonfroni post-hoc tests revealed that in $7^{\text {th }}$ grade, the Druze outperformed the general Arab and Bedouin subgroup on both academic cloze and application of academic vocabulary tests. The general Arab showed higher performance than the Bedouin subgroup on the academic cloze test but not on the production of academic vocabulary test. In $9^{\text {th }}$ grade, no differences were found between the Druze and general Arab on the academic cloze test, both outperforming the Bedouin subgroup. The Druze subgroup showed the highest performance on the production of academic vocabulary test, with no difference between the general Arab and Bedouin subgroup (see Figure 1).

\section{Discussion}

For the first time, the current study attempted to examine academic vocabulary

Table 4. Differences in academic knowledge and production between Arab subgroups.

\begin{tabular}{cccccc}
\hline & Bedouin & Druze & $\begin{array}{c}\text { General Arab } \\
\text { community }\end{array}$ & F & $\eta^{2}$ \\
\cline { 2 - 4 } & M (SD) & M (SD) & M (SD) & & \\
\hline Academic & 91.54 & 92.10 & 93.19 & .49 & .01 \\
Vocabulary & $(10.69)$ & $(10.39)$ & $(11.16)$ & & \\
Declarative Knowledge & & & & \\
Academic Vocabulary & 45.94 & 70.18 & 67.53 & \\
Application in Context & $(29.42)^{\mathrm{c}}$ & $(21.95)^{\mathrm{a}}$ & $(29.33)^{\mathrm{b}}$ & & \\
Academic Vocabulary & 18.49 & 30.33 & 18.32 & \\
Production in Context & $(15.58)^{\mathrm{b}}$ & $(11.56)^{\mathrm{a}}$ & $(17.00)^{\mathrm{b}}$ & $31.30^{* * *}$ & .05 \\
\hline
\end{tabular}

${ }^{* * *} p<.001$. Letters indicating significant differences. 


\section{$7^{\text {th }}$ grade}

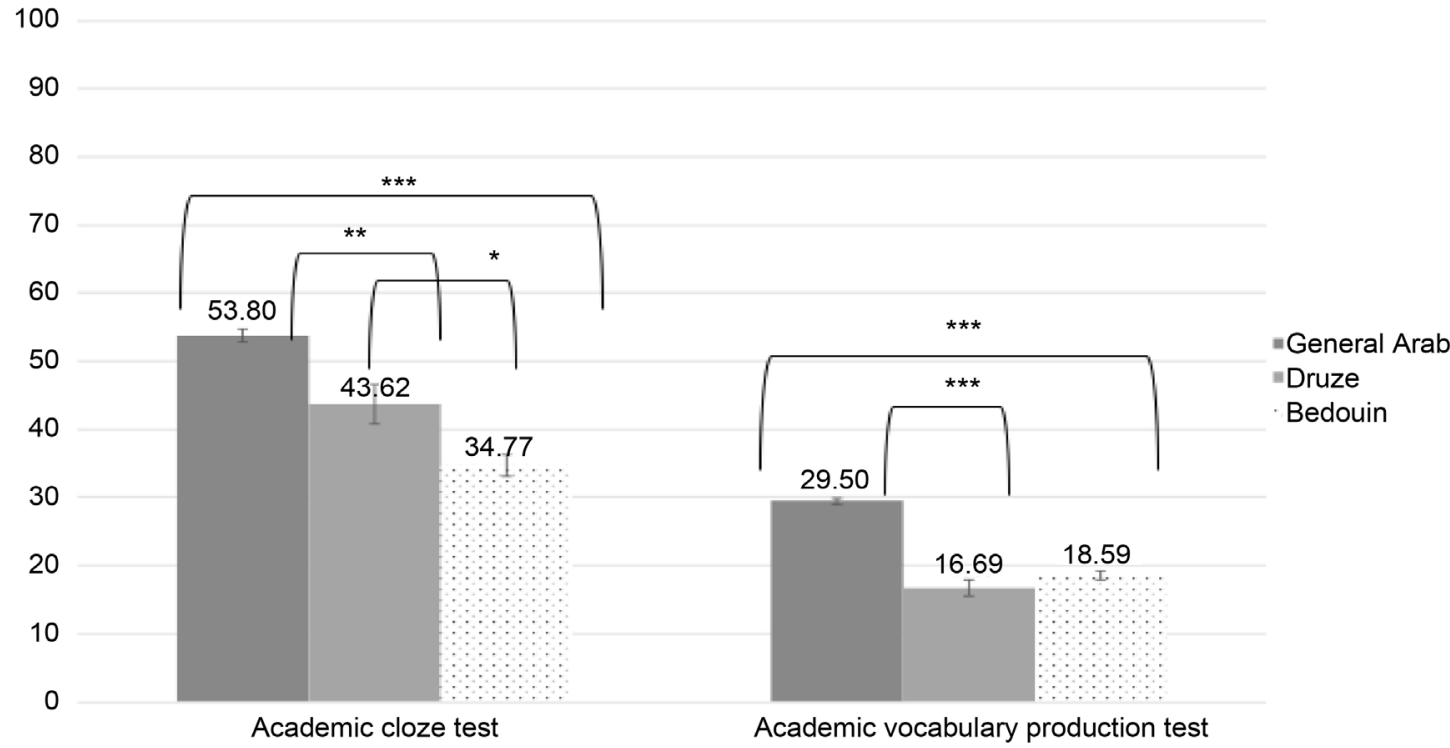

$9^{\text {th }}$ grade

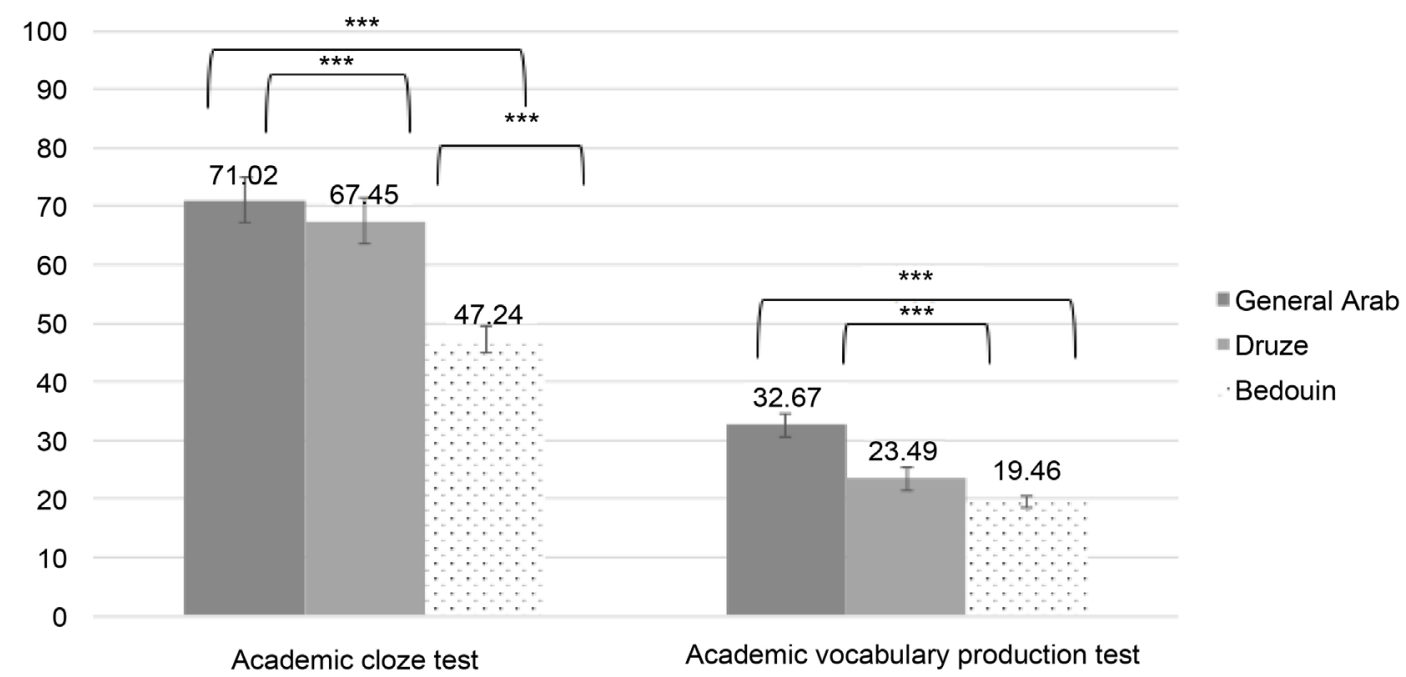

Figure 1. Differences in academic cloze test and academic vocabulary production test between the Arab subgroups in $7^{\text {th }}$ and $9^{\text {th }}$ grad.

knowledge of native Arabic speakers in middle school. The importance of such investigation was documented in studies conducted in other languages, mostly among English learners pointing to the impact of academic vocabulary on academic attainments in general and literacy performance in specific (e.g. Carlo et al., 2004). With regard to the Arabic language, although notable escalation in the investigation of literacy development has been noted in the recent decade, research remains premature, focusing mainly on the ramifications of diglossia in relation to early language acquisition and reading development thus neglecting its impact on later literacy development and academic success. The impact of 
Arabic diglossic nature on literacy development seems to persist also throughout adolescence and even adulthood. As can be seen from national and international literacy test reports, the observed attainment gaps among elementary aged Arabic native speaking children, continue to exist in middle school. For example, as can been seen in the PISA 2012 report, gaps in reading attainments among $8^{\text {th }}$ graders are encountered between Israeli Arabic native speakers and their Hebrew speaking peers, the latter scoring 109 points higher than the former. In addition, while Hebrew native speakers showed a 45 points increase between the years 2002 and 2012, Arabic native speakers showed only 23 points increase. Furthermore, the study data showed that in comparison to $16 \%$ of Hebrew native speakers, $50 \%$ of the Arab children were considered as having reading difficulties. Similar pattern of results was obtained in the study when examining science literacy performance. Arab pupils scored 98 points fewer than their Hebrew speaking peers.

Following this alarming observations, we attempted to shed a light on the readiness of Arabic native speaking middle school pupils to cope with the scholastic materials and demands across the different knowledge domains, relating to age differences and discrepancies in socio-cultural factors, focusing on academic word knowledge as being a potential major contributor to the observed lag in literacy attainments. Such investigation is crucial, considering the escalating curriculum requirements, entailing higher academic language proficiency and depending among other on academic vocabulary knowledge. For this purpose and in an innovative initiative, a corpus-based Arabic academic vocabulary list was developed, mapping the academic words necessary for adequate coping with the scholastic materials across the different disciplines in middle school. Based on the developed list, three evaluation tests were developed: yes/no-academic vocabulary test, academic cloze test and application of academic vocabulary test.

First, to examine the developmental trend in academic vocabulary knowledge, we compared the performance of the pupils on the three evaluation tests between the two age groups ( $7^{\text {th }}$ grade and $9^{\text {th }}$ grade). As indicated by the results, higher academic vocabulary knowledge was observed in $9^{\text {th }}$ grade when compared to $7^{\text {th }}$ grade across all measures, pointing to an increase in academic vocabulary knowledge throughout middle school. However, despite such improvement, both among $7^{\text {th }}$ and $9^{\text {th }}$ graders, the pupils' scores were extremely low on both the academic cloze and application of academic vocabulary tests and that is despite of the obtained high familiarity rates with academic words on the yes/no academic vocabulary test. In total, the results suggest that Arab middle school pupils arrive to middle school with a cumulative gap $s$ that persists also in $9^{\text {th }}$ grade.

An interesting observation was the obtained gap in performance on the yes/no-academic vocabulary tests and the academic cloze and production tests vocabulary test that may reflect a discrepancy between their size of vocabulary repertoire and the depth of their word knowledge. However, such gap may raise concerns regarding the reliability and validity of yes/no vocabulary tests as the 
utilized measure in the current study relied on pupils' self-reports, being among other prone to over-estimation of the actual knowledge. Moreover, future study is solicited to also include productive academic vocabulary measures as the utilized tests in our study reflect only receptive academic vocabulary knowledge.

Another important finding is related to the gaps in academic vocabulary knowledge between the Arab-subgroups, replicating the previously found impact of the socio-cultural factors on literacy development, as found on both national and international tests (Israeli Ministry of Education, 2015), and here on vocabulary knowledge among the Arab population in Israel. Independently of age group, when compared to the General Arab and Druze subgroup, Bedouins, who are characterized by significantly lower socio-economic status, showed the lowest achievements on the three evaluation tests. Such findings stress the importance of deferential remedial instruction and policy change in the Israeli Arab educational system that endeavor to close the gaps between the groups in the different literacy domains, especially in vocabulary knowledge.

\section{The Study Implications and Directions for Practice and Future Research}

As suggested by our study when observing the pupils mean scores in the different evaluation tests, $7^{\text {th }}$ graders commence junior high school with poor vocabulary knowledge which in turn affects their ability to cope with the academic demands in middle school. Accordingly, the developed academic vocabulary list in the current study might serve as a framework for devising early direct vocabulary instruction intervention program that will assist to close the accumulated gaps in academic vocabulary knowledge in middle school. For example, currently, we have been working on devising a teacher-student multi-componential research based remedial literacy program that attempts to address the Arab pupils' literacy needs in middle school. The objective of the intervention programs is to allow extensive exposure to a large academic vocabulary repertoire and to deepen processing of words, which will contribute to reading comprehension abilities across the different disciplines. On the teacher level, it will assist in building an experimentally validated interventional model for Arabic instruction that will address the pedagogical needs for fostering Arabic literacy skills in all schools. With regard to policy change, a main objective will be to induce change in the Arab educational system by implementing a structured and better-suited Arabic and digital literacy promotion and examine its suitability for Arabic literacy instruction across the different age groups and Arab subgroups in Israel.

Furthermore, we are working on validating productive and receptive Arabic vocabulary measures that will enable us to achieve better understanding of pupils' academic vocabulary knowledge level and development. For example, it is of great importance to investigate the receptive/productive dimension of Arabic academic knowledge and its relationship to reading comprehension and academic writing skills. 


\section{References}

Abu-Asba, H. (2005). The Arabic Educational System in Israel: Development and Present Picture. Arab Society in Israel: Population, Society, Economy, 7, 201-221.

Abu-Bader, S., \& Gottlieb, D. (2009). Poverty, Education and Employment in the Arab-Bedouin Society: A Comparative View. Working Paper Series 137. Verona: ECINEQ, Society for the Study of Economic Inequality.

Abu-Rabia, S. (2000). Effects of Exposure to Literary Arabic on Reading Comprehension in a Diglossic Situation. Reading and Writing, 13, 147-157. https://doi.org/10.1023/A:1008133701024

Adalah, The Legal Center for Arab Minority Rights in Israel (2011). The Inequality Report: The Palestinian Arab Minority in Israel. Haifa: The Legal Center for Arab Minority Rights in Israel.

Anderson, R. C., \& Freebody, P. (1983). Reading Comprehension and the Assessment and Acquisition of Word Knowledge. Advances in Reading Language Research, 2, 231-56.

Augustine, C. H., Juvonen, J., Le, V. N., Kaganoff, T., \& Constant, L. (2004). Problems and Promise of the American Middle School. In Focus on the Wonder Years: Challenges Facing the American Middle School. Arlington, VA: Rand Corporation.

Bailey, A. L. (2007). The Language Demands of School: Putting Academic English to the Test. New Haven, CT: Yale University Press.

Campion, M. E., \& Elley, W. B. (1971). An Academic Vocabulary List. Wellington, New Zealand: New Zealand Council for Educational Research.

Carlo, M. S., August, D., McLaughlin, B., Snow, C. E., Dressler, C., Lippman, D. N., Lively, T. T., \& White, C. E. (2004). Closing the Gap: Addressing the Vocabulary Needs of English-Language Learners in Bilingual and Mainstream Classrooms. Reading Research Quarterly, 39, 188-215. https://doi.org/10.1598/RRQ.39.2.3

Central Bureau of Statics (2016). Society in Israel: Israel's Future Generation, Children and Youth up to Age 24 (Report No. 8). Jerusalem: The State of Israel. (In Hebrew)

Cockrum, W. A., \& Shanker, J. L. (2012). Locating and Correcting Reading Difficulties (10th ed.). Sydney, NSW: Pearson.

Cohen, A., Glasman, H., Rosenbaum-Cohen, P. R., Ferrara, J., \& Fine, J. (1988). Reading English for Specialized Purposes: Discourse Analysis and the Use of Standard Informants. In P. Carrell, J. Devine, \& D. Eskey (Eds.), Interactive Approaches to Second Language Reading (pp. 152-167). Cambridge: Cambridge University Press. https://doi.org/10.1017/CBO9781139524513.017

Coxhead, A. (2000). A New Academic Word List. TESOL Quarterly, 34, 213-238. https://doi.org/10.2307/3587951

Coxhead, A., \& Nation, P. (2001). The Specialized Vocabulary of English for Academic Purposes. In J. Flowerdew, \& M. Peacock (Eds.), Research Perspectives on English for Academic Purposes, Chapter: The Specialised Vocabulary of English for Academic Purposes (pp. 252-267). Cambridge: Cambridge University Press. https://doi.org/10.1017/CBO9781139524766.020

Cummins, J. (2003). Reading and the Bilingual Student: Fact and friction. In G.G. Garcia (Ed.), English Learners: Reaching the Highest Level of English Literacy (pp. 2-33). Newark, DE: International Reading Association.

Edi-Rokah, A., Biran, H. \& Fridman-Goldberg, S. (2011). Junior High School: Characteristics and Challenges, an Ordered Review as a Background Material for a Language and Literacy Committee. (In Hebrew) http://education.academy.ac.il

Fang, Z., Schleppegrell, M. J., \& Cox, B. E. (2006). Understanding the Language Demands 
of Schooling: Nouns in Academic Registers. Journal of Literacy Research, 38, 247-273. https://doi.org/10.1207/s15548430jlr3803_1

Ferguson, C. A. (1959). Diglossia. Word, 14, 47-56. https://doi.org/10.1080/00437956.1959.11659702

Friedlander, D., Okun, B. S., \& Goldscheider, C. (2016). Ethno-Religious Hierarchy in Educational Achievement and Socioeconomic Status in Israel: A Historical Perspective. In N. Khattab, S. Miaari, \& S. Haya (Eds.), Socioeconomic Inequality in Israel: $A$ Theoretical and Empirical Analysis (pp. 97-122). London: Palgrave Macmillan. https://doi.org/10.1057/9781137544810_6

Gardner, D., \& Davies, M. (2014). A New Academic Vocabulary List. Applied Linguistics, 35, 305-327. https://doi.org/10.1093/applin/amt015

Ghadessy, M. (1979). Frequency Counts, Word Lists and Materials Preparation: A New Approach. English Language Teaching Forum, 17, 24-27. https://doi.org/10.1017/9781316155752.006

Hakuta, K., Butler, G. Y., \& Witt, D. (2000). How Long Does It Take Learners to Attain English Proficiency? Santa Barbara, CA: University of California Linguistic Minority Research Institute.

Halliday, M. A. K. (1993). The Construction of Knowledge and Value in the Grammar of Scientific Discourse: Charles Darwin's the Origin of the Species. In M. A. K. Halliday, \& J. R. Martin (Eds.), Writing Science: Literacy and Discursive Power (pp. 86-105). Pittsburgh, PA: University of Pittsburgh Press.

Hyland, K., \& Tse, P. (2007). Is There an "Academic Vocabulary"? TESOL Quarterly, 41, 235-253. https://doi.org/10.1002/j.1545-7249.2007.tb00058.x

Israeli Ministry of Education (2015). Meitzav Achievement Report. Ramat Gan: RAMA. (In Hebrew) http://meyda.education.gov.il/files/rama/Hesegim_Report_2015.pdf

Karmarski, B., \& Mevarech, Z. (2004). Reading Literacy, Mathematics and Science. PISA Study 2002: Scientific Report, Ramat Gan: School of Education, Bar Ilan University. (In Hebrew)

Khattab, N. (2002). Ethnicity and Female Labour Market Participation: A New Look at the Palestinian Enclave in Israel. Work, Employment and Society, 16, 91-110. https://doi.org/10.1177/09500170222119263

Knesset Research and Information Center (2013). Background Report on School Outcomes in the Arab Sector. Jerusalem: Kiryat Ben Gurion. (In Hebrew)

Kraus, V., \& Yonay, Y. (2000). The Effect of Occupational Sex-Composition on the Gender Gap in Workplace Authority. Social Science Research, 29, 583-605.

https://doi.org/10.1006/ssre.2000.0683

Lynn, R. W. (1973). Preparing Word Lists: A Suggested Method. RELC Journal, 4, 25-32. https://doi.org/10.1177/003368827300400103

Meara, P. (1996). The Vocabulary Knowledge Framework. Vocabulary Acquisition Research Group Virtual Library. Swansea: Swansea University.

Meara, P. (2010). EFL Vocabulary Tests (2nd ed.). Swansea: Centre for Applied Language Studies, University College of Swansea.

Mevarech, Z. R. \& Karmarsky, B. (2007). Preliminary Results of PISA 2006 in Israel. (In Hebrew)

http://rama.education.gov.il

MJB Special Analysis of Data from the Ministry of Education, Examinations Division and Data Processing Administration (2015) Matriculation Exams Data 2014. Jerusalem. (In Hebrew) 
Nation, I. S. P. (2001). Learning Vocabulary in Another Language. Cambridge: Cambridge University Press. https://doi.org/10.1017/CBO9781139524759

National Institute for Literacy (2007). What Contentarea Teachers Should Know about Adolescent Literacy. Washington DC: National Institute of Child Health and Human Development.

National Insurance Institute of Israel, Research and Planning Administration (2016). Annual Survey 2015. Jerusalem: The State of Israel.

OECD (2014). PISA 2012 Results: What Students Know and Can Do-Student Performance in Mathematics, Reading and Science (Volume I, Revised ed.). Pisa: OECD Publishing.

Pearson, P. D., Hiebert, E. H., \& Kamil, M. L. (2007). Vocabulary Assessment: What We Know and What We Need to Learn. Reading Research Quarterly, 42, 282-296. https://doi.org/10.1598/RRQ.42.2.4

Praninskas, J. (1972). American University Word List. London: Longman.

Qian, D. (1999). Assessing the Roles of Depth and Breadth of Vocabulary Knowledge in Reading Comprehension. Canadian Modern Language Review, 56, 282-308. https://doi.org/10.3138/cmlr.56.2.282

Richards, J. C. (1976). The Role of Vocabulary Teaching. TESOL Quarterly, 10, 77-89. https://doi.org/10.2307/3585941

Rudnitzky, A. (2012). The Bedouin Population in the Negev: Social, Demographic and Economic Factors. Jerusalem: The Abraham Fun Initiatives.

Saiegh-Haddad, E. (2017). Learning to Read Arabic. In L. Verhoeven, \& C. Perfetti (Eds.), Learning to Read across Languages and Writing Systems (pp. 104-126). Cambridge: Cambridge University Press.

Saiegh-Haddad, E., \& Henkin-Roitfarb, R. (2014). The Structure of Arabic Language and Orthography. In E. Saiegh-Haddad, \& M. Joshi (Eds.), Handbook of Arabic Literacy (pp. 3-28). Berlin: Springer. https://doi.org/10.1007/978-94-017-8545-7_1

Schleppegrell, M. J. (2001). Linguistic Features of the Language of Schooling. Linguistics and Education, 12, 431-459. https://doi.org/10.1016/S0898-5898(01)00073-0

Schmitt, N., \& Meara, P. (1997). Researching Vocabulary through a Word Knowledge Framework. Studies in Second Language Acquisition, 19, 17-36.

https://doi.org/10.1017/S0272263197001022

Short, D. J., \& Fitzsimmons, S. (2007). Double Work. Challenges and Solutions to Acquiring Language and Academic Literacy for Adolescent English Language Learners. A Report to Carnegie Corporation of New York, New York, NY: Carnegie Corporation.

Stahl, S. A., \& Shiel, T. G. (1992). Teaching Meaning Vocabulary: Productive Approaches for Poor Readers. Reading and Writing Quarterly: Overcoming Learning Difficulties, 8, 223-241. https://doi.org/10.1080/0748763920080206

Townsend, D. (2009). Building Academic Vocabulary in after School Settings: Games for Growthwith Middle School English Learners. Journal of Adolescent \& Adult Literacy, 53, 242-251. https://doi.org/10.1598/JAAL.53.3.5

Townsend, D., Filippini, A., Collins, P., \& Biancarosa, G. (2012). Evidence for the Importance of Academic Word Knowledge for the Academic Achievement of Diverse Middle School Students. The Elementary School Journal, 112, 497-518.

https://doi.org/10.1086/663301

Xue, G., \& Nation, I. S. P. (1984). A University Word List. Language Learning and Communication, 3, 215-229.

Yonay, P. Y., Yaish, M., \& Kraus, V. (2015). Religious Heterogeneity and Cultural Diffu- 
sion: The Impact of Christian Neighbors on Muslim and Druze Women's Participation in the Labor Force in Israel. Sociology, 49, 660-678.

https://doi.org/10.1177/0038038514547898

Zuzovsky, R. (2005). Achievement of 8th Graders in Mathematics and Science and the Educational Context of Teaching These Subjects in Israeli Schools. Tel Aviv: Ramot-Tel Aviv University. (In Hebrew)

Zuzovsky, R. (2010). The Impact of Socioeconomic versus Linguistic Factors on Achievement Gaps between Hebrew-Speaking and Arabic-Speaking Students in Israel in Reading Literacy and in Mathematics and Science Achievements. Studies in Educational Evaluation, 36, 153-161. https://doi.org/10.1016/j.stueduc.2011.02.004 